\title{
THE TAXATION OF FINANCIAL CAPITAL UNDER ASYMMETRIC INFORMATION AND THE TAX- COMPETITION PARADOX
}

\author{
WOLFGANG EGGERT \\ MARTIN KOLMAR \\ CESIFO WORKING PAPER NO. 1074 \\ CATEGORY 1: PUBLIC FinANCE \\ NOVEMBER 2003 \\ An electronic version of the paper may be downloaded \\ - from the SSRN website: \\ - from the CESifo website: \\ www.SSRN.com \\ www.CESifo.de
}




\title{
THE TAXATION OF FINANCIAL CAPITAL UNDER ASYMMETRIC INFORMATION AND THE TAX- COMPETITION PARADOX
}

\begin{abstract}
This paper examines information sharing between governments in an optimal taxation framework. We present a taxonomy of alternative systems of international capital income taxation and characterize the choice of tax rates and information exchange. The model reproduces the conclusion of the previous literature that integration of international capital markets may lead to the under-provision of publicly provided goods. However, contrary to the existing literature under-provision occurs because of inefficiently coordinated expectations. We show that there exists a second equilibrium with an efficient level of public good provision and complete and voluntary information exchange between national tax authorities.

JEL Classification: F42, F20, H21.
\end{abstract}

Keywords: tax competition, information exchange.

\author{
Wolfgang Eggert \\ University of Konstanz \\ Department of Economics \\ PO Box D 133 \\ 8457 Konstanz \\ Germany
}

Wolfgang.Eggert@uni-konstanz.de

\author{
Martin Kolmar \\ Johannes-Gutenberg-University of Mainz \\ Department of Economic Theory \\ 55099 Mainz \\ Germany
}

We thank Eric W. Bond, Vitor Gaspar, Harry Huizinga and seminar participants in Hannover, Helsinki and Dublin for comments and stimulating discussions. The paper was started while Eggert visited the EPRU at the University of Copenhagen. The author thanks this institution for its hospitality and gratefully acknowledges financial support from the research network 'The Analysis of International Capital Markets: Understanding Europe's role in the Global Economy', funded by the European Commission under the Research Training Network Programme (Contract No. HPRN-CT-1999-00067). The activities of the EPRU are supported by a grant from the Danish National Research Foundation. Kolmar acknowledges financial support by the German Research Foundation. 


\section{Introduction}

The enforcement of an effective taxation of savings income has been a long-standing issue both in policy and in academic debates. In particular, residence-based taxation of capital income - the taxation of a country's residents regardless of the income's source - has often been advocated. A potential drawback of this form of taxation, however, is that the tax can be easily evaded if the residence country is unable to monitor the investor's foreign interest income. This scenario has relevance in the absence of international information-exchange agreements between countries. Without information exchange, source-based forms of taxation constitute the relevant tax types from the perspective of any outside investor. Since most countries abstain from levying taxes at the income's source there is a widespread belief that interest income may completely escape taxation (Keen 1993). It is thus not surprising that the taxation of savings income on a residence basis continues to be a frequently advocated tax principle in policy debates, although previous work on international taxation concludes that it will most probably not be in the national self-interest to report information to foreign tax authorities (as, e.g., Tanzi 1995).

Interestingly, irrespective of the perceived mistrust in the ability of tax authorities to sustain a system of information exchange between sovereign countries, prominent recent policy recommendations as the OECD (2002) initiative and the proposal of the European Commission (2001) focus on such a system. At least the European proposal seems to receive much more support among member states than previously thought. On the council meeting in January 2003 European governments have agreed to exchange information about interest incomes of non-resident investors with other member states. The agreement explicitly introduces residence-based taxation of savings after almost 13 years of diplomatic wrangling on the savings-tax issue.

The OECD initiative and the European agreements are supported by previous literature on capital-tax competition. It is a standard result in this literature that the adverse effects of decentralized decision-making by governments on welfare could be neutralized if the residence principle were applicable for the taxation of international capital income (Razin and Sadka 1991, Bucovetsky and Wilson 1991). ${ }^{1}$ However, this

\footnotetext{
${ }^{1}$ The intuition is that the residence based capital tax is the only tax that allows to control the savings of residents. It is for this reason that distortions caused by decentralized tax setting in the in the 'basic tax competition model' (cf. Wilson 1999) introduced by Zodrow and Mieszkowski (1986) can directly be attributed to the non-existence of a tax on world wide capital income of residents.
} 
previous work does not formally address the question how governments can possibly obtain the information required to monitor the worldwide capital income of residents.

The correspondence between the findings and recommendations of theoretical research and the success of actual tax agreements, thus, is by no means obvious. The crucial question is whether it is in the self-interest of the national tax authorities to truthfully report the information necessary to establish a residence-based system of capital taxation. The results provide an answer to the question about the potential success of the above-mentioned information-exchange treaties, which goes to the heart of the discussion about the residence principle.

Qualitatively there may be two reasons to withhold information. Both arguments rely on the effect that withholding information reduces the tax burden placed on the interest income of savers, which causes an inflow of financial capital. According to the first argument, this inflow may cause an outward shift of the production possibility frontier of a country and it may create favorable tax-base effects. Countries will then choose to withhold information to attract financial capital. This observation would lead to the conclusion that the incentives of individual countries do not coincide with collective rationality, since the latter calls for information exchange to make residencebased capital income taxation sustainable. As a consequence, the first argument suggests that information-exchange treaties are not credible without the establishment of a supra-national agency that enforces contracts to overcome the Prisoners' Dilemma in information policy. The second potential reason for the withholding of information is based on a co-ordination failure between the countries. This case belongs to a class of economic environments where multiple equilibria exist and policy faces an equilibriumselection problem. In the second scenario information exchange is an equilibrium, but countries may be stuck in the no-information equilibrium because of inefficiently coordinated expectations. Countries may perceive a conflict between individual rationality and collective rationality in the second case. In contrast to the first argument, however, countries can co-ordinate their expectations on a different equilibrium during negotiations. Efficient co-ordination can explain the empirical observation that fully sovereign countries choose to sign tax treaties.

The relevant scenario can, however, not be deduced from empirical observations alone. We rather have to identify the basic economic mechanism that underlies tax treaties. Some preceding papers analyzed the problem of information exchange in difFor a discussion see Eggert and Haufler (1999). 
ferent contexts. Bacchetta and Espinosa $(1995,2000)$ analyze the issue in an economy with source taxes on real capital and exogenously given tax rates in a static (1995) and a repeated game (2000). Information withholding attracts real capital and thereby increases both, total production and tax revenues of the economy. Hence, their main conclusion is that information exchange cannot be supported as an equilibrium of the static game. However, in the repeated game they characterize punishment strategies and reciprocity norms that are sufficient to guarantee the exchange of information. Eggert and Kolmar (2002) identify an economic environment where information withholding does neither create direct nor tax-base effects. However, if the size of the financial sector is of importance for the production potential of an economy, information withholding may become rational again. In the same spirit, Huizinga and Nielsen (2003) focus on the existence of bank profits as a possible explanation for why countries may have an incentive to withhold information. Bank profits depend on the quantity of investments in a given country, hence, tax authorities have an incentive to withhold information. In a repeated version of the game the authors can show, however, that information exchange can be sustained as an equilibrium if the discount factor is sufficiently small.

What is missing in the discussion so far is the explicit consideration of different regimes for the taxation of financial capital. This paper attempts to close this gap by explicitly considering different tax regimes on financial capital. Accordingly we analyze two central questions. First, what are the economic effects of information policies in different tax regimes? And, second, if the participation in an agreement on information exchange were voluntary, would the agreement be undermined by countries which are linked through perfect capital mobility?

Our main results are as follows. We show that the fiscal authorities cannot generate tax revenues from source-based taxes on savings in the Nash equilibrium if capital is perfectly mobile. It is this case which underlies most of the previous work that forecast the inefficiency of decentralized tax setting. It is one of the major insights of the paper that this effect paves the way for the voluntary exchange of information. Countries choose to exchange information on the income of non-residents exactly because they perceive the tax base of any capital tax to be infinite elastic in the absence of information-exchange agreements. This is what we call the tax-competition paradox: capital-market integration eliminates a Prisoners' Dilemma in which tax agreements are not an equilibrium exactly because countries are confronted with perfect capitalmarket integration. As a consequence, governments can effectively use a residence tax, and the presence of residence-based capital-income taxation ensures that decentralized 
decision-making by governments is efficient. However, we also show that an equilibrium with less desirable welfare properties coexists. In this equilibrium the tax authorities co-ordinated expectations inefficiently choose not to exchange information with foreign tax authorities.

The paper proceeds as follows. Section 2 presents the model before we derive the basic results concerning information exchange and the tax structures in Sections 3 and 4 . Section 5 summarizes.

\section{The model with portfolio-capital flows}

We consider a version of the 'basic' tax-competition model (cf. Wilson 1999) introduced by Zodrow and Mieszkowski (1986) with two identical countries, $i=1,2$. Countries are linked through perfect capital mobility and are assumed to be small in the sense that each takes the international price for capital as given. Each country is inhabited by a representative individual and firms in both countries produce a homogeneous good. We adapt the model for the taxation of financial capital and the strategic use of information exchange in an economic environment where individuals choose their savings and labor supply.

As in Bacchetta and Espinosa $(1995,2000)$ we will assume that the issue of information exchange is more fundamental than a decision about tax rates, essentially because it is included in tax treaties. A decision about an information policy basically determines whether a residence-based tax is available or not, but the information policy does not prevent countries from choosing their tax rates in accordance with specific fiscal needs. In detail, we consider the following game structure that will be explained in the following:

\begin{tabular}{lll}
\hline \multicolumn{1}{c}{ Stage 1 } & \multicolumn{1}{c}{ Stage 2 } \\
$\begin{array}{ll}\text { Governments } \\
\text { non-cooperatively and }\end{array}$ & $\begin{array}{l}\text { Sovernments } \\
\text { non-cooperatively and }\end{array}$ & $\begin{array}{l}\text { Period 1: Individuals make a } \\
\text { savings decision. }\end{array}$ \\
$\begin{array}{l}\text { simultaneously commit to a } \\
\text { system of information }\end{array}$ & $\begin{array}{l}\text { simultaneously commit to } \\
\text { tax rates on wage and capital }\end{array}$ & $\begin{array}{l}\text { Period 2: Individuals choose } \\
\text { labor supply, firms produce }\end{array}$ \\
income. & and tax revenue is spent.
\end{tabular}

Governments and institutions. Even in a two-country economy the flows of real and financial capital induce a complicated net of transactions. This net is represented in Figure 1. The arrows indicate the flows of financial capital investments and the knots the bases for different taxes. In line with most of the literature on capital tax 
competition we assume that individuals in country, say, $i$ can invest there savings in the financial sector either at home or abroad (see, among others, Wildasin 1988, Keen and Marchand 1997, Brueckner 2000). Financial intermediaries ('banks') in both countries may invest in the rest of the world (row), at the same time individuals have limited options for their worldwide financial investment. ${ }^{2}$ The existence of an international market for financial capital then ensures that savings are allocated in the country where the after-tax rate of return is highest, implying equalization of lending and borrowing interest rates worldwide (as in, for example, Wildasin 1988, Keen and Marchand 1997, p. 231 and p. 36 , respectively).

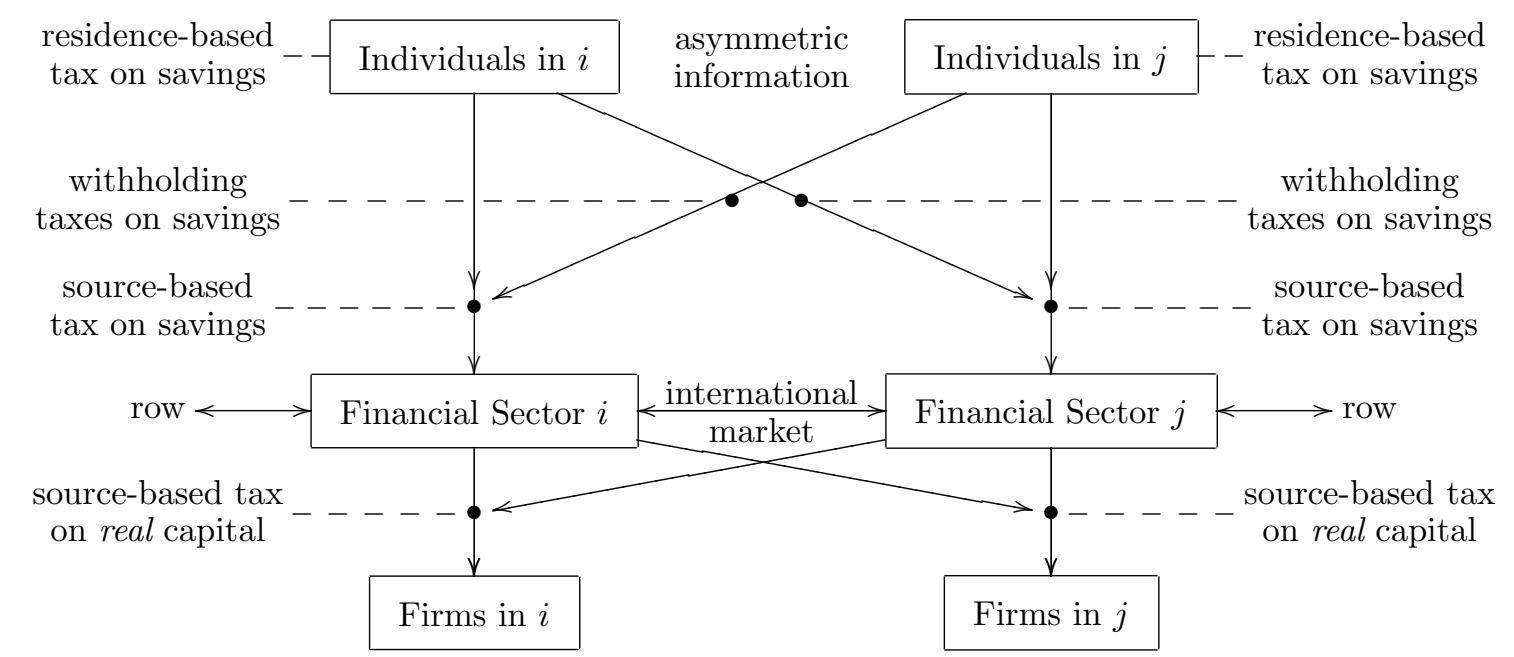

Figure 1: Institutional structure of capital taxation.

We assume that national tax authorities can only force banks residing within the country to report truthfully the amount of savings invested, but not banks abroad. Hence, the government has to rely on the information given by tax authorities in the competing country to enforce the residence-based tax on worldwide capital income. If this information is incomplete, capital income is composed of declared and taxed income and undeclared and untaxed income. We adopt the convention used in Bacchetta and Espinosa (1995), Huizinga and Nielsen (2003) and assume that each tax authority chooses the fraction $\lambda$ of non-residents' savings it reports to the tax authority in the country where the investor resides. In order to make the model analytically tractable

\footnotetext{
${ }^{2}$ This assumption is made for analytical convenience and without relevance for the results. It has some empirical plausibility though. The Deutsche Bundesbank (1994) estimated that the announcement of a $10 \%$ withholding in Germany tax caused a capital outflow of 99.5 bill. DM in 1989 . The by far largest part of it was channeled through affiliates of German banks located in Luxembourg.
} 
we assume that information is either completely exchanged or not exchanged at all.

Alternative systems of income taxation Previous literature on capital-tax competition has analyzed the interaction of a wage tax with the source-based tax on real capital. Razin and Sadka (1991) demonstrate that a tax authority in a small open economy chooses not to tax real capital investment of firms on a source basis conditional to the presence of a positive level of wage taxation. The intuition for this result is based on the following arguments. The source tax on real capital distorts the production decision of firms. The wage tax, in contrast, distorts the individual's labor-leisure choice. It follows then from an application of the Diamond and Mirrlees (1971) production-efficiency theorem that the production tax will not be used by the government because this tax ultimately falls on wage income and, additionally, causes a production distortion. The latter can be avoided by directly taxing wage income. In order to have a lean set of tax instruments, we will make use of the theorem and exclude a source tax on productive capital from the set of instruments in the following. The absence of source-based taxes on real capital allows it to use the terms 'savings' and '(financial) investments' as synonyms throughout the analysis, both referring to the financial side of the economy.

In our setting each tax authority has three different tax instruments at its disposal (Figure 1). All taxes are in the interval [0,1]. Take country $i$ as an example. First, it can choose the rate $t_{i}^{w}$ at which it taxes wage income $w_{i} l_{i}$, where $w_{i}$ denotes the wage rate and $l_{i}$ is labor supply. Second, it can choose to tax the capital income of residents at rate $t_{i}^{r}$. Tax revenues, however, depend on the status of information exchange by the other country. Residence-based capital taxation can be implemented if the foreign country chooses to exchange information and sets $\lambda_{j}=1$. Then the tax base is $R s_{i}=R\left(s_{i}^{i}+s_{i}^{j}\right)$, where $R$ is the world return to capital and $s_{i}^{i}, s_{i}^{j}$ denotes the amount of savings that $i$-residents invest at home and abroad, respectively. We note that $s_{i}=s_{i}^{i}+s_{i}^{j}$. If information is not exchanged then $t_{i}^{r}$ will turn out to be a tax on the income of $i$ residents generated in country $i$ alone. Third, the government may tax capital income generated at home on a source basis, $t_{i}^{s}$.

The discrimination between residents and non-residents under source-based forms of taxation has been prominent in policy debates, as the OECD (1998) guidelines demonstrate. The economic consequences of a preferential tax treatment are in the center of recent work by Keen (2001) and Janeba and Smart (2003), and we also allow for preferential tax treatment in this paper. The source tax $t_{i}^{s}$ we consider can take two forms, dependent on the parameter $\phi$, which is the rate at which countries include 
their residents' interest income in the source-tax base. The following table summarizes the link between tax rates and tax bases:

\begin{tabular}{c|cccc} 
& wage tax & $\begin{array}{c}\text { residence-based tax } \\
\text { on interest income }\end{array}$ & $\begin{array}{c}\text { source-based tax } \\
\text { on interest income }\end{array}$ & $\begin{array}{c}\text { withholding tax } \\
\text { on foreigners }\end{array}$ \\
\hline tax rate & $t_{i}^{w}$ & $t_{i}^{r}$ & $t_{i}^{s}$ at $\phi=1$ & $t_{i}^{s}$ at $\phi=0$ \\
tax base & $w_{i} l_{i}$ & $R\left(s_{i}^{i}+\lambda_{j} s_{i}^{j}\right)$ & $R\left(s_{i}^{i}+s_{j}^{i}\right)$ & $R s_{j}^{i}$
\end{tabular}

We use the standard convention - and the notation used in Figure 1 - that a source-based tax is a tax levied in the country of the income's source independent of the investor's residency. A tax on investment by foreigners is called a withholding tax. With this terminology we can distinguish between two cases. In the first case, $\phi=1$, the government treats resident and foreign investors equal. This source-tax regime is analyzed in Section 3. In the second case, $\phi=0$, country $i$ exempts residents' interest income generated at home from the tax base. Hence, if $\phi=0, t_{i}^{s}$ specifies a withholding tax on the capital income generated at home by foreign residents. We discuss this case in Section 4.

Given the taxes introduced above, the net wage a resident in country $i$ obtains for each unit of labor, $\omega_{i}$, is linked to the gross wage, $w_{i}$, by the definition $\omega_{i}:=w_{i}\left(1-t_{i}^{w}\right)$. We also use

$$
\rho_{i}^{i}:=R\left(1-t_{i}^{r}-t_{i}^{s} \phi\right) \quad \text { and } \quad \rho_{i}^{j}:=R\left(1-\lambda_{j} t_{i}^{r}-t_{j}^{s}\right)
$$

where $t_{i}^{r}+t_{i}^{s} \phi$ and $\lambda_{j} t_{i}^{r}+t_{j}^{s}$ is the effective tax paid by residents of country $i$ on the capital income generated in country $i$ and country $j$, respectively. Thus, $\rho_{i}^{i}$ is the net of tax interest rate residents of country $i$ obtain for investments in country $i$ and $\rho_{i}^{j}$ is the net return which residents of country $i$ receive from investments in country $j$. With this notation, the system of taxation of capital income established in country $i$ is described by a vector $\left\{t_{i}^{w}, t_{i}^{r}, t_{i}^{s}, \lambda_{j}, \phi\right\}$, where the first three components are chosen by the country itself, whereas the fourth component is the level of information exchange chosen by country $j$.

\subsection{The market equilibrium under alternative tax systems}

We solve the game by backward induction, starting determining the market equilibrium at Stage 3. 
Firms. Production takes place under conditions of perfect competition with a constant-returns-to-scale production function $f\left(k_{i}, l_{i}^{d}\right)$, which relates output of the consumption good to the level of (real) capital investment, $k_{i}$, and the amount of labor employed, $l_{i}^{d}$. The zero-profit condition is $f\left(k_{i}, l_{i}^{d}\right)-w_{i} l_{i}^{d}-R k_{i}=0$, where $R$ denotes the (exogenous) world interest rate and $w_{i}$ is the national (gross) wage rate. The conditions for optimal factor pricing are $\partial f\left(k_{i}, l_{i}^{d}\right) / \partial k_{i}=R$ and $\partial f\left(k_{i}, l_{i}^{d}\right) / \partial l_{i}=w_{i}$.

Households. The representative household in, say, country $i$ maximizes lifetime utility subject to both period's budget constraints. The utility function is $\nu\left(c_{i 1}, c_{i 2}, l_{i}\right)+$ $u\left(g_{i}\right)$. It is assumed to be well-behaved and, for analytical convenience, separable between consumption and labor, $c_{i 1}, c_{i 2}, l_{i}$, and the national public good, $g_{i}$. Let us denote by $e_{i}$ an endowment that individuals obtain at the beginning of the first period. ${ }^{3}$ The endowment can either be consumed, $c_{i 1}$, or saved, $s_{i}$. The household can either save at home, $s_{i}^{i}$, or abroad, $s_{i}^{j}, s_{i}=s_{i}^{i}+s_{i}^{j}$. The budget constraint in the first period is $c_{i 1}=e_{i}-s_{i}^{i}-s_{i}^{j}, i \neq j$.

In the second period the household chooses labor supply, $l_{i}$, and receives savings income plus the principal. Residents in country $i$ earn a net return of $\rho_{i}^{i}$ for every unit saved at home, and they earn a net return of $\rho_{i}^{j}$ for every unit saved abroad. The secondperiod budget constraint is $c_{i 2}=\omega_{i} l_{i}+\left(1+\rho_{i}^{i}\right) s_{i}^{i}+\left(1+\rho_{i}^{j}\right) s_{i}^{j}$. In subsequent analysis we follow Bucovetsky and Wilson (1991, pp. 340-341) assuming that the cross-price derivatives of compensated factor supply functions are negative. ${ }^{4}$

Using the budget constraints in the direct utility function gives the utility function as a function of $s_{i}^{i}, s_{i}^{j}$, and $l_{i}$ :

$$
\nu\left(e_{i}-s_{i}^{i}-s_{i}^{j}, \omega_{i} l_{i}+\left(1+\rho_{i}^{i}\right) s_{i}^{i}+\left(1+\rho_{i}^{j}\right) s_{i}^{j}, l_{i}\right)+u\left(g_{i}\right) .
$$

Denoting by subscripts partial derivatives, the first-order conditions for a utility maximum are $\nu_{c_{1}} / \nu_{c_{2}} \geq 1+\rho_{i}^{i}, \nu_{c_{1}} / \nu_{c_{2}} \geq 1+\rho_{i}^{j}$ and $\nu_{l_{i}} / \nu_{c_{1}}=-\omega_{i}$. A comparison of the first and second condition defines the arbitrage condition between investment at home and

\footnotetext{
${ }^{3}$ To make the tax problem interesting we assume that the endowment cannot be taxed. It is assumed to be sufficiently large to avoid that individuals take out loans in the first period. The present modelling of the individual's problem is adapted from Bucovetsky and Wilson (1991).

${ }^{4}$ Hence, $\partial l^{c} / \partial \rho<0$ and $\partial s^{c} / \partial \omega<0$, where a superscript $c$ denotes compensated functions. The assumption implies that wage and residence taxes on capital income are positive in the optimum. See King (1980) for a discussion of the role of compensated demand elasticities of leisure and second-period consumption for the optimum savings tax in a related framework.
} 
investment abroad. Inspection of the first-order conditions shows that the household will not invest at home as long as $\rho_{i}^{i}<\rho_{i}^{j}$. Let us assume that individuals prefer to save at home in case of indifference. We summarize the arbitrage opportunities at a given vector of after-tax prices as follows:

Lemma 1. (a) If $\rho_{i}^{i} \geq \rho_{i}^{j} \Rightarrow s_{i}=s_{i}^{i} \wedge s_{i}^{j}=0$. (b) If $\rho_{i}^{i}<\rho_{i}^{j} \Rightarrow s_{i}=s_{i}^{j} \wedge s_{i}^{i}=0$.

It can be seen from Lemma 1 that there can be discrete jumps in the allocation of savings that result from marginal changes in the net return to capital, $\rho_{i}^{i}$ and $\rho_{i}^{j}$, at $\rho_{i}^{i}=\rho_{i}^{j}$. For a given world-interest rate, $R$, and a given vector of government instruments, $\left\{t_{i}^{r}, t_{i}^{s}, t_{i}^{w}, \lambda_{i}, t_{j}^{r}, t_{j}^{s}, t_{j}^{w}, \lambda_{j}, \phi\right\}$, we can define an equilibrium as a pair of prices $\left\{w_{i}, w_{j}\right\}$ which is compatible with profit and utility maximization and simultaneously fulfills the market-clearing conditions for national labor markets, $l_{i}^{d}=l_{i}$ and $l_{j}^{d}=l_{j}$. Inserting the equilibrium values of $c_{i 1}, c_{i 2}, l_{i}$ into the utility function yields an indirect utility function $v\left(t_{i}^{r}, t_{i}^{s}, t_{i}^{w}, \lambda_{i}, t_{j}^{r}, t_{j}^{s}, t_{j}^{w}, \lambda_{j}, \phi\right):=\max _{c_{i 1}, c_{i 2}, l_{i}} \nu\left(c_{i 1}, c_{i 2}, l_{i}\right) .^{5}$

Tax authorities. For a given information policy $\left\{\lambda_{i}, \lambda_{j}\right\}$ every national authority maximizes the indirect utility function of its representative household at Stage $2, W_{i}=$ $v\left(t_{i}^{r}, t_{i}^{s}, t_{i}^{w}, \lambda_{i}, t_{j}^{r}, t_{j}^{s}, t_{j}^{w}, \lambda_{j}, \phi\right)+u\left(g_{i}\right)$, by the choice of a tax policy $\left\{t_{i}^{w}, t_{i}^{r}, t_{i}^{s}\right\}$ taking as given the tax policy of the other country. A Nash equilibrium at Stage 2 is a fixed point in tax policies. Tax revenues are used to finance the public good. For simplicity we assume that the quantity of the public good, $g_{i}$, is equal to the tax revenues:

$$
g_{i}=t_{i}^{w} w_{i} l_{i}+\left(t_{i}^{s} \phi+t_{i}^{r}\right) R s_{i}^{i}+t_{i}^{r} \lambda_{j} R s_{i}^{j}+t_{i}^{s} R s_{j}^{i} .
$$

The changes in the indirect utility function due to a tax change are given by ${ }^{6}$

$$
\frac{d W_{i}}{d x_{i}}=\frac{d v_{i}}{d x_{i}}+\frac{d u}{d g_{i}} \frac{d g_{i}}{d x_{i}}, \quad x \in\left\{t_{i}^{s}, t_{i}^{r}, t_{i}^{w}\right\}
$$

In line with the literature on optimal taxation we assume that the tax problem is convex (Atkinson and Stiglitz 1980). We then have to characterize the equilibrium tax policy with associated welfare levels for every realization of information policies $\left\{\lambda_{i}, \lambda_{j}\right\} \in$ $\{\{1,1\},\{0,1\},\{1,0\},\{0,0\}\}$ for both, $\phi=1$ and $\phi=0$. In the following we denote by $W_{i}\left(\lambda_{i}, \lambda_{j}\right)$ the equilibrium levels of welfare given the equilibrium at Stage 2 for either

\footnotetext{
${ }^{5}$ We omit $R$ in the domain of the indirect utility function for simplicity because it is no choice variable of the tax authorities. The equilibrium wage rates do not occur in the indirect utility function because they are functions of the government instruments.

${ }^{6}$ Note that $d$ might indicate discrete jumps for changes in information and taxes from Lemma 1.
} 
$\phi=1$ or $\phi=0$. Finally, both countries non-cooperatively maximize their welfare levels $W_{i}\left(\lambda_{i}, \lambda_{j}\right)$ taking as given the choice of information exchange by the other country. A Nash equilibrium of the game at Stage 1 is a fixed point in the information parameters. ${ }^{7}$

\section{Source taxation}

\subsection{Tax policies}

We will start with an analysis of the case where countries do not discriminate between residents and non-residents in tax matters. This corresponds to the non-preferential tax regime that underlies the OECD (1998) guidelines, in which governments do not exempt residents from source-based taxation, $\phi=1$. Using (1), Lemma 1 reads:

Lemma 2. If $\phi=1$ then $t_{j}^{s}\left\{\begin{array}{l}\geq\left(1-\lambda_{j}\right) t_{i}^{r}+t_{i}^{s} \Rightarrow s_{i}=s_{i}^{i} \wedge s_{i}^{j}=0, \\ <\left(1-\lambda_{j}\right) t_{i}^{r}+t_{i}^{s} \Rightarrow s_{i}=s_{i}^{j} \wedge s_{i}^{i}=0 .\end{array}\right.$

The inequality in Lemma 2 measures the tax differential an individual residing in country $i$ faces when making his investment decision. We may now characterize the tax strategies of the governments in each country in three different cases: first, both governments simultaneously exchange information; second, both governments do not exchange information, and, third, exactly one country exchanges information.

Tax rates with information exchange. In the case of full information exchange the countries will not use the source tax but rely on both, the wage and residence tax. Intuitively, the second-best efficient allocation can be implemented by the use of wageand residence taxes alone. There is no need for a source tax in this case.

In order to make the intuition precise we start with the source taxes first and demonstrate that $t_{i}^{s}=t_{j}^{s}=0$ is the only candidate for an equilibrium. In order to do so assume on the contrary that source-based capital taxes are non-zero in at least one country for arbitrary rates of the wage tax and the residence-based capital income tax. For example it follows from $\lambda_{j}=1$ that the government in country $i$ can implement a residence-based tax on $i$-residents, which cannot be circumvented and hence does not enter the arbitrage condition of the individual residing in $i$ (see Lemma 2). However, the

\footnotetext{
${ }^{7}$ It is well known that a Nash equilibrium in pure strategies need not exist if the strategy space is not continuous. As we will see this problem does not occur in the present model.
} 
source tax on capital income taxation is relevant for the decision of individuals where to invest. Start by assuming that country $i$ imposes a slightly higher source-based tax than country $j$. It will only be able to collect the wage tax and the residence-based tax as all financial investment will be in country $j$. The government in country $i$ can reduce $t_{i}^{s}$ to attract savings. Tax arbitrage by investors implies that the reduction of $t_{i}^{s}$ will neither affect the level of $s_{i}$ nor the level of $s_{j}$ as long as $t_{i}^{s}>t_{j}^{s}$. However, at $t_{i}^{s}=t_{j}^{s}$ we get an inflow of savings from $i$-residents. If $t_{j}^{s}=0$, the tax cut does not generate a tax-base effect. However, if $t_{s}^{j}>0$ there exists a positive tax-base effect. On the other hand, the individual decision is still unchanged because there is no change in the relative prices. Hence, each country wins or is indifferent by setting $t_{i}^{s}=t_{j}^{s}$.

If $t_{j}^{s}>0$ and country $i$ further reduces $t_{i}^{s}$, we get a second-order loss of tax revenues collected from residents and an additional second-order effect because of the change in relative prices faced by residents. However, these second-order effects are over-compensated by the first-order effect resulting from the additional tax revenues from the reallocation of investments country $j$-residents previously invested abroad. ${ }^{8}$

Given that $t_{i}^{s}=t_{j}^{s}=0$ we can now derive the structure of $t_{i}^{r}$ and $t_{i}^{w}$ from their first-order conditions (3):

$$
\begin{aligned}
& \frac{d W_{i}}{d t_{i}^{r}}=-R s_{i} \frac{\partial \nu}{\partial c_{i 2}}+R \frac{\partial u}{\partial g_{i}}\left[s^{i}-R\left[\frac{\partial s_{i}^{i}}{\partial \rho_{i}^{i}}+\frac{\partial s_{i}^{i}}{\partial \rho_{i}^{j}}+\frac{\partial s_{i}^{j}}{\partial \rho_{i}^{i}}+\frac{\partial s_{i}^{j}}{\partial \rho_{i}^{j}}\right] t_{i}^{r}-w_{i}\left[\frac{\partial l_{i}}{\partial \rho_{i}^{i}}+\frac{\partial l_{i}}{\partial \rho_{i}^{j}}\right] t_{i}^{w}\right]=0, \\
& \frac{d W_{i}}{d t_{i}^{w}}=-w_{i} l_{i} \frac{\partial \nu}{\partial c_{i 2}}+w_{i} \frac{\partial u}{\partial g_{i}}\left[l_{i}-R \frac{\partial s_{i}^{i}}{\partial \omega_{i}} t_{i}^{r}-R \frac{\partial s_{i}^{j}}{\partial \omega_{i}} t_{i}^{r}-w_{i} \frac{\partial l_{i}}{\partial \omega_{i}} t_{i}^{w}\right]=0 .
\end{aligned}
$$

Take a pair $\left\{t_{i}^{r}, t_{i}^{w}\right\}$ such that both conditions are fulfilled. At that point we know that $R s_{i} d W_{i} / d t_{i}^{w}-w_{i} l_{i} d W_{i} / d t_{i}^{r}=0$. Solving the latter expression yields:

$$
\frac{t_{i}^{r}}{t_{i}^{w}} \frac{R}{w_{i}}=\frac{s_{i} \frac{\partial l_{i}}{\partial \omega_{i}}-l_{i}\left(\frac{\partial l_{i}}{\partial \rho_{i}^{i}}+\frac{\partial l_{i}}{\partial \rho_{i}^{j}}\right)}{l_{i}\left(\frac{\partial s_{i}^{i}}{\partial \rho_{i}^{i}}+\frac{\partial s_{i}^{i}}{\partial \rho_{i}^{j}}+\frac{\partial s_{i}^{j}}{\partial \rho_{i}^{i}}+\frac{\partial s_{i}^{j}}{\partial \rho_{i}^{j}}\right)-s_{i}\left(\frac{\partial s_{i}^{i}}{\partial \omega_{i}}+\frac{\partial s_{i}^{j}}{\partial \omega_{i}}\right)} .
$$

${ }^{8}$ To see the argument formally, consider that the government in country $i$ chooses $t_{i}^{s}$ such that $t_{i}^{s}=t_{j}^{s}-\epsilon, \epsilon>0, \epsilon \rightarrow 0$. The policy has two effects. First, the direct effect of a tax cut on residents' utility is $R s_{i}^{i} \partial \nu / \partial c_{i 2}>0$. Second, the loss of tax revenue from the source tax is equal to $-\epsilon R s_{i}^{i} \rightarrow 0$. Third, behavioral changes induce marginal changes in tax revenues that are equal to $-t_{i}^{w} w_{i} \partial l_{i} / \partial t_{i}^{s}-t_{i}^{r} R \partial s_{i} / \partial t_{i}^{s}$. Fourth, tax revenues increase because a $j$-resident re-allocates capital to country $i$ at $t_{i}^{s}<t_{j}^{s}$, which implies an increase in tax revenues that is equal to $t_{i}^{s} R s_{j}^{i}$. This discrete change over-compensates the marginal changes of effects two and three. Hence, country $i$ chooses $t_{i}^{s}<t_{j}^{s}$ as long as $t_{j}^{s}>0$. At $t_{j}^{s}=0$ it follows immediately that $\partial W_{i} / \partial t_{i}^{s}=0$ since a tax increase would immediately and completely crowd out savings. 
Using the Slutsky equation we find from (4) that $0<t_{i}^{r} / t_{i}^{w}<\infty$ under the assumption that the cross-price derivatives of compensated factor supply functions are negative. We may then summarize the results in the case of full information exchange:

Result 1. There exists a unique equilibrium of the subgame at Stage 2 for $\lambda_{i}=\lambda_{j}=1$ that can be characterized as follows: $t_{i}^{s}=t_{j}^{s}=0$, and the governments in both countries use wage and residence-based capital taxation.

The observation that neither the residence-based capital tax nor the wage tax do distort the international investment decision of savers has an interesting normative implication:

Corollary 1. (Razin and Sadka 1991, Bucovetsky and Wilson 1991) The Nash equilibrium with full exchange of information is globally efficient given the available taxes. A combined effort to raise tax rates in all countries will not increase welfare.

The argument is derived from the observation that neither $R$ nor $w_{i}$ is a function of $t_{j}^{s}, t_{j}^{r}$, or $t_{j}^{w}$. Hence, we can conclude that $W_{i}\left(t_{i}^{r}, t_{i}^{s}, t_{i}^{w}, t_{j}^{r}, t_{j}^{s}, t_{j}^{w}\right)=$ $W_{i}\left(t_{i}^{r}, 0, t_{i}^{w}, 0,0,0\right) \forall t_{j}^{s}, t_{j}^{r}, t_{j}^{w}$ at $\lambda_{i}=\lambda_{j}=1$. The intuition for the finding is that the place of investment is irrelevant for the tax payments when residence-based capital taxation can be implemented by governments. Since the source-based capital-income tax is zero already, the incentives of governments to strategically choose taxes to attract capital are eliminated. There exists no externality between both countries that destroys second-best efficiency.

Tax rates without information exchange. We demonstrate that both, residence and source taxes are equal to zero if both countries withhold information. Hence, countries exclusively rely on the wage tax to finance the public good. This finding results from the perfect integration of capital markets where individuals can and will use arbitrage opportunities due to tax differentials if they exist. Hence, any positive source or residence tax - which is equal to a selective tax on savings by residents at home in the case without information exchange - in one country will create the incentive in the other country to undercut this tax rate in order to attract a discrete quantity of savings, thereby increasing tax revenues. Even a home-bias in the sense that for equal net-interest rates individuals prefer to invest at home does not change this logic because the individuals are ultimately motivated by their monetary income. 
If all capital taxes are equal to zero, wage taxation alone has to be used to fulfill the budget constraint (2) and the first-order condition for $t_{i}^{w}(3)$. The latter constraint can be rewritten to obtain

$$
t_{i}^{w}=l_{i}\left(1 /\left(w_{i} \partial l_{i} / \partial w_{i}\right)-\left(\partial \nu / \partial c_{i 2}\right) /\left(\partial u / \partial g_{i}\right)\right)
$$

Result 2. There exists a unique equilibrium of the subgame at Stage 2 for $\lambda_{i}=\lambda_{j}=0$ that can be characterized as follows: $t_{i}^{s}=t_{j}^{s}=t_{i}^{r}=t_{j}^{r}=0$, and governments use only wage taxation to fulfill the budget constraint (2).

The formal proof of this and the following results is tedious and is therefore relegated to the Appendix. The result reflects the frequently perceived fear that capital taxcompetition undermines the ability to raise tax revenue from capital income taxation. The downward competition in taxes leads to a lower level of tax revenue and publicgood provision, compared to a situation in which tax competition is absent.

Tax rates with asymmetric information exchange. If information is asymmetrically exchanged we get a combination of the two previous cases. If $\lambda_{i}=0, \lambda_{j}=1$ $\left(\lambda_{i}=1, \lambda_{j}=0\right)$ only country $i(j)$ can effectively use its residence-based capital tax. As a consequence, it will use only wage and residence taxes. It is thereby able to implement the second-best optimum. Country $j$, however, will not be able to use its source tax because the use of this tax would drive all savings out of its country. As a consequence, country $i$ would have a 'free lunch' by taxing these foreign savings.

Result 3. There exists a unique equilibrium of the subgame at Stage 2 for $\lambda_{i}=0, \lambda_{j}=$ 1 that can be characterized as follows: $t_{i}^{s}=t_{j}^{s}=t_{j}^{r}=0$. The tax authority in country $j$ only uses wage taxation and the tax authority in country $i$ uses both, residence and wage taxation to fulfill the budget constraint in (2). The tax rates are characterized by (5) and (4).

\subsection{Information policies}

Let us denote by $W_{i}\left(\lambda_{i}, \lambda_{j}\right)$ the welfare level in country $i$ given information policies $\left\{\lambda_{i}, \lambda_{j}\right\}$, and, analogously, denote by $W_{j}\left(\lambda_{j}, \lambda_{i}\right)$ the welfare level in country $j$. The small-country assumption separates both countries' labor markets as can be seen from the first-order conditions of firms above. Results 1-3 then imply that

$$
W_{i}(1,1)=W_{i}(0,1) \quad \text { and } \quad W_{i}(1,0)=W_{i}(0,0),
$$


because the equilibrium tax rates in both inequalities are the same for all those taxes with positive tax rates. The first equality results from a comparison of Result 1 and Result 3 for country $i$, whereas the second equality stems from a comparison of Result 2 and Result 3. The key to understand the equation on the l.h.s. of (6) is that even if country $i$ stops reporting information and thereby making it more attractive for a $j$-resident to investment in country $i$, it is indifferent because it will not collect tax revenues from the additional investment. The main explanation for the equation on the r.h.s. of (6) is that information exchange by country $i$ does help to effectively implement residence-based taxation in country $j$. However, this has no effect on welfare in country $i$ since the tax bases of capital taxes are zero if the government in country $i$ chooses to tax capital.

We can now derive the equilibrium strategies at Stage 1. The maximization problem of country $i$ is $\max _{\lambda_{i}} W_{i}\left(\lambda_{i}, \lambda_{j}\right)$. By the same token, $\max _{\lambda_{j}} W_{j}\left(\lambda_{j}, \lambda_{i}\right)$ is the maximization problem of country $j$. A Nash equilibrium is a fixed point $\left\{\lambda_{i}^{N}, \lambda_{j}^{N}\right\}$. Assume that $\lambda_{j}=1$. Country $i$ compares $W_{i}(1,1)$ with $W_{i}(0,1)$. It follows from $(6)$ that $\lambda_{i}=1$ is a best response to $\lambda_{j}=1$ and vice versa. On the other hand, let $\lambda_{j}$ be equal to 0 . Country $i$ has the choice between $W_{i}(1,0)$ and $W_{i}(0,0)$. Inspection of the equation on the r.h.s. of (6) shows that $\lambda_{i}=0$ is a best response to $\lambda_{j}=0$ and vice versa.

Result 4. With a source tax on capital full information exchange as well as no information exchange are Nash equilibria between the countries.

We will interpret the implications of Result 4 after the analysis of withholding taxation in the next section.

\section{Withholding taxation}

\subsection{Tax policies}

In the preferential-tax regime we analyze in this section each tax authority exempts its own residents from source-based taxation and implements a withholding tax on foreigners, $\phi=0$. Then, the arbitrage condition given in Lemma 1 simplifies as follows:

Lemma 3. If $\phi=0$, then $t_{j}^{s}\left\{\begin{array}{l}\geq\left(1-\lambda_{j}\right) t_{i}^{r} \Rightarrow s_{i}=s_{i}^{i} \wedge s_{i}^{j}=0, \\ <\left(1-\lambda_{j}\right) t_{i}^{r} \Rightarrow s_{i}^{j}=s_{i} \wedge s_{i}^{i}=0 .\end{array}\right.$ 
As in the preceding section we analyze the equilibrium tax policies for different information scenarios in turn.

Tax rates with information exchange. If information is exchanged, Lemma 3 implies that $s_{i}=s_{i}^{i}$ if and only if $t_{j}^{s} \geq 0$, and $s_{j}=s_{j}^{j}$ if and only if $t_{i}^{s} \geq 0$. Hence, the tax revenues from the withholding tax are always equal to zero; either the tax rate or the tax base is equal to zero because of an infinitely high elasticity of savings. Different to the case analyzed in the last section, however, the exemption of residents from the source tax gives rise to multiple equilibria. Every pair of tax rates $\left\{t_{i}^{s}, t_{j}^{s}\right\}$ is an equilibrium because residents cannot avoid the residence tax and therefore prefer to invest at home. The foreign source-tax rate can never influence this decision. As a consequence, both countries maximize welfare by the choice of wage and residence taxes. The structure of the maximization problems is identical to the one with a zero source tax, and (4) characterizes the optimum.

Result 5. Equilibria of the subgame at Stage 2 for $\lambda_{i}=\lambda_{j}=1$ exist and can be characterized as follows: countries choose an arbitrary withholding-tax rate whose revenues are equal to zero, and they set wage and residence taxes according to (4).

Tax rates without information exchange. If both countries do not exchange information, $\lambda_{i}=\lambda_{j}=0$, individuals have the choice between the residence tax when investing at home and the withholding tax when investing abroad. In such a situation, the tax revenues from capital taxation must be equal to zero because otherwise at least one country would have an incentive to selectively attract at least one tax base by slightly undercutting the other country's tax rate.

Result 6. Equilibria of the subgame at Stage 2 for $\lambda_{i}=\lambda_{j}=0$ exist and can be characterized as follows. (1) Tax revenues from capital taxes are always equal to zero. (2) Either the residence-tax rates are equal to zero and the source tax rates are arbitrary, the source-tax rates are equal to zero and the residence-tax rates are arbitrary, or one country chooses both taxes to be equal to zero and the other country chooses arbitrary residence- and withholding-tax rates. Both countries use the wage tax according to (5).

The multiplicity of equilibria is again a consequence of the selective nature of the withholding tax. In the case of zero residence taxes, for example, all savings are invested in the home countries. Hence, every possible withholding tax is compatible with this allocation of savings because their tax base is always equal to zero. By the same token, 
if both withholding taxes are equal to zero, all savings are invested abroad, and the residence taxes are either zero or have a zero tax base. The third tax-rate scenario also has an intuitive explanation: if one country has attracted all savings, this country has to set both capital taxes equal to zero in order not to be undercut by the other country. If it sets the tax rates to zero, however, every source-tax rate and every positive residence-tax rate by the other country is compatible with this allocation of savings, As a consequence, information exchange turns out to be crucial for the effective taxation of capital. Without information exchange the countries cannot place part of the tax burden on capital.

Tax rates with asymmetric information exchange. We finally analyze the case where $\lambda_{i}=0$ and $\lambda_{j}=1$. The economic intuition is similar to the one given for the previous cases and we therefore restrict attention to present the result.

Result 7. Equilibria of the subgame at Stage 2 for $\lambda_{i}=\lambda_{j}=0$ exist and can be characterized as follows. (1) Tax revenues from the withholding tax in both countries and from the residence tax in country $j$ are always equal to zero. (2) The residencetax rate is equal to zero in $j$ and the source tax rates are arbitrary. The wage tax for country $j$ is obtained from (5), whereas the wage and residence tax rates for country $i$ are given by (4).

\subsection{Information policies}

As before, the exogenous interest factor separates both countries' labor markets. This implies that we find the same structure as in Section 3.2 when comparing the welfare levels of different information policies,

$$
W_{i}(1,1)=W_{i}(0,1) \quad \text { and } \quad W_{i}(1,0)=W_{i}(0,0) .
$$

The intuition for (7) is that the countries can only collect tax revenues from capital taxation if the other country provides information about foreign investments. Without this information tax revenues from capital income taxation are necessarily equal to zero despite the fact that capital can be taxed at source since either the tax rate or the tax base is zero. For this reason the increase of financial investment by foreigners that results from information withholding is irrelevant for the government in country $i$. Hence, we get a result similar to Section 3.2. 
Result 8. With a withholding tax on foreign capital, full information exchange as well as no information exchange are Nash equilibria between the countries.

What are the implications of Results 4 and 8 ? The first conclusion is that the withholding of information is in fact a rational strategy for the countries given that countries expect that the other withhold information too. This finding replicates the view of most previous analysis on capital tax competition that decentralized tax setting of fiscal authorities leads to an underprovision of public goods. However, the economic mechanisms that generate this result are different because here results are caused by a coordination-failure between countries. The expectation that taxes are set inefficiently can turn out to be self-fulfilling. However, efficiency is a viable opportunity if countries manage to coordinate their expectations on the information-exchange equilibrium. This equilibrium exists because of the perfect integration of capital markets with the implied elimination of positive revenues from source or withholding taxes. ${ }^{9}$

In a small, open economy, the withholding of information may be of interest for a country if it can generate additional tax revenues from the use of source or withholding taxes. Perfectly integrated markets, however, eliminate this strategic incentive by driving taxes levied at the income's source to zero. To put it differently, the worst case of tax competition paves the way for information exchange and thereby efficiency of decentralized tax setting. Competition in tax rates credibly ties the hands of fiscal authorities so that they have no incentive to engage in information competition. We call this effect the tax-competition paradox. In the light of this finding, the best way to achieve efficient taxation of capital income is to deepen international capital-market integration.

\footnotetext{
${ }^{9}$ In Bucovetsky (1991) and Wilson (1991) differences in population size are essential for the structure of results because the difference determines the ability of fiscal policy to manipulate the world interest rate. This paper assumed countries of equal size in order to simplify the exposition. Our results extend to a situation with countries that differ in population size as long as one country does not become infinitesimal small. The argument is that the results we obtain are driven by the discrete changes in tax revenues resulting from marginal changes in tax rates. Competition will eliminate the possibility to generate tax revenues from any source-based tax on financial capital as long as such discrete effects are present.
} 


\section{Conclusions}

Perfect capital mobility has been frequently seen as a source for economic growth, but, at the same time, also as a major threat to fiscal authorities. The results of this paper suggest that under specific circumstances the globalization of tax bases as such may not be as harmful for countries as previously thought. Exactly when capital mobility is perfect there exists an equilibrium with efficient decentralized decision-making. Competition eliminates the incentives to withhold information because it eliminates all the taxes that are potential candidates for information-induced tax-base effects. Hence, it is not the presence of perfect capital mobility that causes an inefficiency of decentralized decision-making by governments. This is what we have labeled the tax-competition paradox in the introduction.

A short recapitulation of our main results reveals the basic mechanisms. (i) First, both, source-based taxation and withholding taxation of financial capital are identical with respect to their equilibrium welfare levels irrespective of the fact that their tax bases differ. The intuition is that the tax elasticity of financial capital is large enough to drive revenues from source and withholding taxes to zero, reducing the set of effectively available tax instruments to wage and residence taxes. (ii) Second, tax competition is not a Prisoners' Dilemma in our model. Capital mobility ensures that governments are unable to use the tax system to manipulate the allocation of tax bases. As a consequence, governments do not treat information exchange as a cost when capital markets are integrated.

The multiplicity of equilibria may be a key factor for the explanation of the current tax treaties discussed in the introduction. It is undisputed that no-information exchange is in fact an equilibrium between countries, and in fact it is the equilibrium we observe today between most countries. However, there also exist the treaties mentioned in the introduction, which rely on the voluntary participation of sovereign countries (Boadway 2001). If the underlying problem to be solved by these treatments is a Prisoners' Dilemma, a theory-based prediction for their success must be very pessimistic. However, voluntary participation in information-exchange treaties becomes viable if multiple equilibria exist. It is then a question to coordinate expectations, and this may be the primary function of the treaties. ${ }^{10}$

\footnotetext{
${ }^{10} \mathrm{~A}$ short remark on the theoretical literature concerning multiple equilibria is in order here. Huizinga and Nielsen (2003) and Bacchetta and Espinosa (2000) show how punishment strategies can be used to induce information exchange as an equilibrium in an infinitely repeated game. The
} 


\section{Appendix}

\section{Proof of Result 2}

Existence: Assume that $t_{i}^{r}=t_{i}^{s}=t_{j}^{r}=t_{j}^{s}=0$, which implies that all savings are invested in the country where the investor resides, $s_{i}=s_{i}^{i}$, and $s_{j}=s_{j}^{j}$. Given that $t_{j}^{r}=t_{j}^{s}=0$, it follows immediately that there is no profitable deviation for country $i$. If country $i$ increases its residence-tax rate their residents will reallocate their savings to country $j$. Hence, total tax revenues remain zero, and the country is indifferent. By the same token, if country $i$ increases its source-tax rate their residents will reallocate their savings to country $j$. Again, total tax revenues remain zero, and the country is indifferent. Finally, any combined increase in residence and source taxes has the same effect.

Uniqueness: Given an arbitrary vector of capital-tax rates $\left\{t_{i}^{r}, t_{i}^{s}, t_{j}^{r}, t_{j}^{s}\right\}$, with at least one tax rate being strictly positive, we will show that then there always exists a profitable deviation for at least one country. Four cases that have to be considered:

Case 1: $t_{j}^{s} \geq t_{i}^{r}+t_{i}^{s} \wedge t_{i}^{s} \geq t_{j}^{r}+t_{j}^{s}$, which implies that all savings are invested in the country where the investor resides. The tax inequalities imply that $-t_{i}^{r} \geq t_{j}^{r}$, which can only be fulfilled if $t_{i}^{r}=t_{j}^{r}=0$. This implies that $t_{i}^{s}=t_{j}^{s}$ in order to make it rational for the individuals to invest at home. A marginal reduction of the source tax by, say, country $i$ then has the following effects on its welfare. (i) The relative price of savings with respect to consumption and labor supply changes, which induces behavioral changes by the individuals, and thereby general-equilibrium effects on the equilibrium wage rate. These effects have a direct effect on utility as well as an indirect effect on utility via tax-base effects. (ii) It becomes profitable for foreigners to reallocate their savings to country $i$, which increases country $i$ 's tax revenues by $t_{i}^{s} R s_{j}$. The first-order effect (ii) always over-compensates the second-order effect (i), which implies that it is always profitable to reduce the source-tax rate.

Case 2: $t_{j}^{s} \geq t_{i}^{r}+t_{i}^{s} \wedge t_{i}^{s}<t_{j}^{r}+t_{j}^{s}$, which implies that all savings are invested in country $i$. Total tax revenues in country $i$ and $j$ are $T_{i}=t_{i}^{w} w_{i} l_{i}+\left(t_{i}^{r}+t_{i}^{s}\right) R s_{i}^{i}+t_{i}^{s} R s_{j}^{i}$ and $T_{j}=t_{j}^{w} w_{j} l_{j}$. There always exists a profitable deviation for country $j$ as long as at least one tax rate is positive in country $i$ : it can reduce either $t_{j}^{s}$, or $t_{j}^{r}$, or both, until either the savings of foreigners or residents are reallocated to country $j$. This creates a positive tax-base effect because of the assumption that at least one tax rate is positive

creation of an equilibrium selection problem, and the coordination of expectations becomes crucial for the success of efficient punishment strategies. 
in country $i$, which implies that the reallocation occurs at a positive country- $j$ tax rate. If all tax rates are equal to zero in country $i$, country $j$ can induce a reallocation of savings $s_{j}$, but the tax revenues remain zero. Hence, country $j$ is indifferent between the positive tax rate and the tax rate that is equal to zero. Tax rates equal to zero, however, imply that country $i$ is restricted to use the wage tax. A positive tax in country $j$ creates some leeway for the tax authority in country $i$ to increase either the residence or the source tax by a small but positive amount. We know from Result 1 and Corollary 1, however, that efficiency requires the use of both, wage and capital taxes, which implies that such an increase must be profitable for country $i$.

Case 3: $t_{j}^{s}<t_{i}^{r}+t_{i}^{s} \wedge t_{i}^{s} \geq t_{j}^{r}+t_{j}^{s}$, which implies that all savings are invested in country $j$. This case is analogous to Case 2 .

Case $4: t_{j}^{s}<t_{i}^{r}+t_{i}^{s} \wedge t_{i}^{s}<t_{j}^{r}+t_{j}^{s}$, which implies that all savings are invested in the foreign country. In this case total tax revenues in country $i$ and $j$ are $T_{i}=t_{i}^{w} w_{i} l_{i}+t_{i}^{s} R s_{j}^{i}$ and $T_{j}=t_{j}^{w} w_{j} l_{j}+t_{j}^{s} R s_{i}^{j}$. Two cases have to be considered:

(i) $i$-residents invest in country $j$ because the residence-tax rate $t_{i}^{r}$ is sufficiently large (so that a reduction would imply a reallocation of savings). If the source tax in country $j$ is strictly positive $\left(t_{j}^{s}>0\right)$, a reduction of $t_{i}^{r}$ is always profitable because it creates a positive tax-base effect by inducing a reallocation of savings. At $t_{j}^{s}=0$ country $i$ is indifferent because a reallocation of savings requires a reduction of the residence tax such that additional tax revenues are equal to zero. In this case, for a reallocation to occur it must be that $t_{j}^{s}=t_{i}^{s}$. This scenario has already been analyzed in Case 2 where we have shown that a profitable deviation exists. (ii) $i$-residents invest in country $j$ even though the residence tax is zero, $t_{i}^{r}=0$. In this case, however, it must be that $j$-residents invest in country $i$ because of a sufficiently large residence tax $t_{j}^{r}$. This situation is analogous to case (i) analyzed above.

q.e.d.

\section{Proof of Result 3}

Existence: Assume that $t_{i}^{s}=t_{j}^{r}=t_{j}^{s}=0, t_{i}^{r}>0$. Since residents of country $i$ cannot avoid the residence tax, all savings are invested in the country where the investor resides, $s_{i}=s_{i}^{i}$, and $s_{j}=s_{j}^{j}$. Given that $t_{i}^{s}=0$, there exists no profitable deviation for country $j$. If country $j$ increases its residence- or source-tax rate, their residents will reallocate their savings to country $i$. Hence, total tax revenues remain zero, and the country is indifferent. For country $i$ a change is $t_{i}^{r}$ has no effect on the allocation of savings across countries but on the savings decision of residents because of a change in relative prices. Hence, the tax authority maximizes its objective function as if it were 
in a closed economy. Therefore, the optimal tax structure is implicitly given by (4) if $t_{i}^{s}=0$. A change in $t_{i}^{s}$, on the other hand, would induce a reallocation of savings to the foreign country without any consequences for the residents. Hence, tax revenues and utility remain unchanged.

Uniqueness: Given an arbitrary vector of capital-tax rates $\left\{t_{i}^{r}, t_{i}^{s}, t_{j}^{r}, t_{j}^{s}\right\}$, with at least one tax rate in addition to the residence tax in country $i$ being strictly positive. We will show that then there always exists a profitable deviation for at least one country. We have to consider four possible cases again (the residence tax of country $i$ does not enter the arbitrage condition because it cannot be avoided):

Case 1: $t_{j}^{s} \geq t_{i}^{s} \wedge t_{i}^{s} \geq t_{j}^{r}+t_{j}^{s}$, all savings are invested in the residence country. The tax inequalities imply that $t_{j}^{s} \geq t_{i}^{s} \geq t_{j}^{r}+t_{j}^{s} \Rightarrow t_{j}^{r}=0$. This condition can only be fulfilled if $t_{i}^{s}=t_{j}^{s}$ in order to make it rational for the individuals to invest at home. It follows that this case is equivalent to Case 1 in the proof of Result 2.

Case 2: $t_{j}^{s} \geq t_{i}^{s} \wedge t_{i}^{s}<t_{j}^{r}+t_{j}^{s}$, all savings are invested in country $i$, and the revenues from capital taxes are zero in country $j$. Two cases have to be distinguished. (i) If $t_{i}^{s}>0$ country $j$ can always reduce the total tax burden, $t_{j}^{s}+t_{j}^{r}$, until $t_{i}^{s}=t_{j}^{s}+t_{j}^{r}$. At this point the country obtains a discrete increase in tax revenues, $\left(t_{j}^{s}+t_{j}^{r}\right) R s_{j}$, without any additional behavioral changes by the individuals. (ii) If $t_{i}^{s}=0$ only a decrease in $t_{j}^{s}+t_{j}^{r}$ to zero would induce a reallocation of savings. However, this would not change total tax revenues. In this case, however, country $i$ has an incentive to reduce its source-tax rate $t_{i}^{s}$. In order to control for behavioral changes of their residents, it is always possible to reduce $t_{i}^{s}$ such that $t_{i}^{s}+t_{i}^{r}$ remains constant. Moreover, the increase in the source tax rate creates additional tax revenues because of an extension of the tax base to all domestic savings, including both, $s_{i}$ and $s_{j}$.

Case 3: $t_{j}^{s}<t_{i}^{s} \wedge t_{i}^{s} \geq t_{j}^{r}+t_{j}^{s}$, all savings are invested in country $j$. This case is analogous to Case 2.

Case 4: $t_{j}^{s}<t_{i}^{s} \wedge t_{i}^{s}<t_{j}^{r}+t_{j}^{s}$, all savings are invested in the foreign country. Both inequalities are only compatible if $t_{j}^{r}>0$. In this case total tax revenues in country $i$ and $j$ are $T_{i}=t_{i}^{w} w_{i} l_{i}+t_{i}^{s} R s_{j}^{i}+t_{i}^{r} R s_{i}^{i}$ and $T_{j}=t_{j}^{w} w_{j} l_{j}+t_{j}^{s} R s_{i}^{j}$. Note that the positive residence tax in country $j$ creates no tax revenues but acts as a barrier for the inflow of savings. Hence, there exists a $t_{j}^{r} \geq 0$ such that savings of $j$ residents are reallocated to country $j$. Assume that $t_{j}^{r}$ is chosen such that $j$-residents face the same net-interest rate at home and abroad (which implies that they will invest at home by Lemma 1). Such a reduction leads to a discrete increase in tax revenues in country $j$ that is equal to $\left(t_{j}^{r}+t_{j}^{r}\right) R s_{j}^{j}$. This is strictly positive because at least of the tax rates is strictly positive 
in order to fulfill the assumptions of Case 4.

Given that country $i$ is restricted to the use of the residence-based capital income and wage taxation it will maximize welfare according to (4). Given that country $j$ can only use the wage tax in equilibrium it will maximize welfare by choosing the wage tax according to $(5)$.

q.e.d.

\section{Proof of Result 6}

As before we have to check whether all four possible allocations of savings among countries can be supported as equilibria of the game.

Case 1: $t_{j}^{s} \geq t_{i}^{r} \wedge t_{i}^{s} \geq t_{j}^{r}$, all savings are invested in the residence country of the investor. Hence, tax revenues from the withholding tax are equal to zero. Assume that $t_{i}^{r}>0$. In this case country $j$ may choose a tax rate $0<t_{j}^{s}<t_{i}^{r}$ such that $i$-residents reallocate their savings. This creates an increase in tax revenues of $t_{j}^{s} R s_{i}>0$. If $t_{i}^{r}=0$ such a strategy is impossible. On the other hand, if $t_{i}^{s}>0$ it is impossible to gain for country $j$ by lowering $t_{j}^{r}$ because the relevant tax base - savings of residents - is already subject to residence taxation or the residence tax is equal to zero. Hence, $t_{i}^{r}=t_{j}^{r}=0$ and $t_{i}^{s}, t_{j}^{s} \in[0,1]$ are compatible with Case 1.

Case 2: $t_{j}^{s} \geq t_{i}^{r} \wedge t_{i}^{s}<t_{j}^{r}$, all savings are invested in country $i$, and the revenues from capital taxes are zero in country $j$. As before, country $j$ can always gain by sufficiently lowering $t_{j}^{s}$ if $t_{i}^{r}>0$ or $t_{j}^{r}$ if $t_{i}^{s}>0$. If $t_{i}^{r}=t_{i}^{s}=0$, country $j$ is indifferent between all capital-tax rates. However, $t_{j}^{r}=0$ is incompatible with the assumption that all savings are invested in country $i$ because of the home bias.

Case 3: $t_{j}^{s}<t_{i}^{r} \wedge t_{i}^{s} \geq t_{j}^{r}$, all savings are invested in country $j$. This case is analogous to Case 2.

Case 4: $t_{j}^{s}<t_{i}^{r} \wedge t_{i}^{s}<t_{j}^{r}$, all savings are invested in the foreign country. This case is symmetric to Case 1: if $t_{i}^{s}>0$, country $j$ has always an incentive to set $0<t_{j}^{r} \leq t_{i}^{s}$ in order to attract savings of residents. This creates a positive effect for tax revenues. If $t_{i}^{s}=0$, however, country $j$ has no incentive to attract this savings because the effect on tax revenues is zero. Hence, only $t_{i}^{s}=t_{j}^{s}=0$ do not induce any incentive to deviate. Every positive residence-tax rate, however, is compatible with an equilibrium. Given that the countries can only generate revenues by the use of the wage tax they will maximize welfare by choosing it according to (5).

q.e.d.

\section{Proof of Result 7}

Again we have to check whether the possible allocations of savings can be supported 
as equilibria of the game.

Case 1: $t_{j}^{s} \geq 0 \wedge t_{i}^{s} \geq t_{j}^{r}$, all savings are invested in the residence country. If $t_{j}^{r}>0$ there exists a tax rate $0<t_{i}^{s}<t_{j}^{r}$ such that $j$-residents reallocate their savings. This creates an increase in tax revenues of $t_{i}^{s} s_{j}>0$. Hence, $t_{j}^{s}=0$ in equilibrium. The choice of $t_{i}^{r}$ is irrelevant for the allocation of savings among countries because it cannot be avoided. Given that all savings are invested in the residence country, also $t_{i}^{s}$ and $t_{j}^{s}$ are irrelevant and can therefore be set arbitrarily.

Case 2: $t_{j}^{s} \geq 0 \wedge t_{i}^{s}<t_{j}^{r}$, all savings are invested in country $i$. If $t_{i}^{s}>0$, country $j$ can always raise its tax revenues by setting $t_{j}^{r}=t_{i}^{s}$ and thereby attracting $s_{j}$. hence, $t_{i}^{s}=0$ in equilibrium. If $t_{j}^{r}>0$, on the other hand, country $i$ will always increase its tax revenues by setting $t_{i}^{s}=t_{j}^{r}-\epsilon, \epsilon>0, \epsilon \rightarrow 0$ because the tax burden falls completely on the residents of the foreign country. An increase in the tax burden of country- $j$ residents, however, reduces welfare in country $j$. this loss of welfare can be avoided by setting $t_{j}^{r}=0$. If $t_{j}^{r}=t_{i}^{s}=0, t_{j}^{s}$ is irrelevant.

Cases 3 and 4: Both cases would imply $t_{j}^{s}<0$, which can be excluded from our assumption that taxes are in the interval $[0,1]$.

In summary, country $i$ can only generate tax revenues by the use of the wage and the residence tax, whereas country $j$ can only raise tax revenues by the use of the wage tax. Hence, the optimal tax rates are defined by (4) and (5) respectively. q.e.d.

\section{References}

Atkinson, A.B., and J.E. Stiglitz (1980) Lectures on public economics (New York: MacGraw-Hill)

Bacchetta, P., and M.P. Espinosa (1995) 'Information sharing and tax competition among governments.' Journal of International Economics 39, 103-121

— (2000) 'Exchange-of-information clauses in international tax treaties.' International Tax and Public Finance 7, 275-293

Boadway, R. (2001) 'Tax systems in federations and economic unions.' Paper presented at the OCFEB conference 'Tax Policy in the European Union' on 17-19 October 2001

Brueckner, Jan K. (2000) 'A Tiebout/tax competition model.' Journal of Public Economics 77, 285-306 
Bucovetsky, S. (1991) 'Asymmetric tax competition.' Journal of Urban Economics $30,167-181$

Bucovetsky, S., and J.D. Wilson (1991) 'Tax competition with two tax instruments.' Regional Science and Urban Economics 21, 333-350

Deutsche Bundesbank (1994) 'Aufkommen und ökonomische Auswirkungen des steuerlichen Zinsabschlags.' Monatsberichte der Deutschen Bundesbank 46(1), 45-58

Diamond, P.A., and J.A. Mirrlees (1971) 'Optimal taxation and public production.' American Economic Review 61, 8-27 and 261-278

Eggert, W., and A. Haufler (1999) 'Capital taxation and the production efficiency theorem in an open economy.' Economics Letters 62, 85-90

Eggert, W., and M. Kolmar (2002) 'Residence-based capital taxation in a small open economy: why information is voluntarily exchanged and why it is not.' International Tax and Public Finance 9(4), 465-482

European Commission (2001) 'Proposal for a council directive to ensure a minimum of effective taxation of savings income in the form of interest payments within the Community.' COM(2001) 400 final, Brussels

Huizinga, H., and S.B. Nielsen (2003) 'Withholding taxes or information exchange: How to tax international interest flows.' Journal of Public Economics 87, 39-72

Janeba, E., and M. Smart (2003) 'Is targeted tax competition less harmful than its remedies?' International Tax and Public Finance. forthcoming

Keen, M.J. (1993) 'The welfare economics of tax coordination in the european community.' Fiscal Studies 14, 15-36

(2001) 'Preferential regimes can make tax competition less harmful.' National Tax Journal pp. 757-762

Keen, M.J., and M. Marchand (1997) 'Fiscal competition and the pattern of public spending.' Journal of Public Economics 66, 33-53

King, M.A. (1980) 'Savings and taxation.' In Public policy and the tax system, ed. G.A. Hughes and G.M. Heal (London: George Allen \& Unwin) chapter 1, pp. 1-35

OECD (1998) 'Harmful tax competition: an emerging global issue'

OECD (2002) 'Agreement on exchange of information in tax matters'

Razin, A., and E. Sadka (1991) 'International tax competition and gains from tax harmonization.' Economics Letters 37, 69-76 
Tanzi, V. (1995) Taxation in an integrated world (Washington D.C.: The Brookings Institution)

Wildasin, D.E. (1988) 'Nash equilibria in models of fiscal competition.' Journal of Public Economics 35, 229-240

Wilson, J.D. (1991) 'Tax competition with interregional differences in factor endowments.' Regional Science and Urban Economics 21, 423-451 (1999) 'Theories of tax competition.' National Tax Journal 52(2), 269-304

Zodrow, G.R., and P. Mieszkowski (1986) 'Pigou, Tiebout, property taxation and the underprovision of local public goods.' Journal of Urban Economics 19, 356-370 


\section{CESifo Working Paper Series}

(for full list see www.cesifo.de)

1009 Marco Runkel, Optimal Contest Design when the Designer's Payoff Depends on Competitive Balance, August 2003

1010 Donald O. Parsons, Torben Tranaes and Helene Bie Lilleør, Voluntary Public Unemployment Insurance, August 2003

1011 Rüdiger Pethig and Andreas Wagener, Profit Tax Competition and Formula Apportionment, August 2003

1012 Johan Willner, Privatisation and Public Ownership in Finland, August 2003

1013 Seppo Kari and Jouko Ylä-Liedenpohja, Taxation and Valuation of International Real Investments, August 2003

1014 James Heckman, Rosa Matzkin and Lars Nesheim, Simulation and Estimation of Hedonic Models, August 2003

1015 Biswa N. Bhattacharyay, Towards a Macro-Prudential Leading Indicators Framework for Monitoring Financial Vulnerability, August 2003

1016 J. Stephen Ferris and Stanley L. Winer, Searching for Keynes: With Application to Canada, 1870-2000, August 2003

1017 Massimo Bordignon, Luca Colombo and Umberto Galmarini, Fiscal Federalism and Endogenous Lobbies' Formation, August 2003

1018 Annette Alstadsæter, The Dual Income Tax and Firms' Income Shifting through the Choice of Organizational Form and Real Capital Investments, August 2003

1019 Peter Fredriksson and Bertil Holmlund, Optimal Unemployment Insurance Design: Time Limits, Monitoring, or Workfare?, August 2003

1020 Kashif S. Mansori, Following in their Footsteps: Comparing Interest Parity Conditions in Central European Economies to the Euro Countries, August 2003

1021 Christoph Borgmann and Matthias Heidler, Demographics and Volatile Social Security Wealth: Political Risks of Benefit Rule Changes in Germany, August 2003

1022 Kjell Erik Lommerud, Bjørn Sandvik and Odd Rune Staume, Good Jobs, Bad Jobs and Redistribution, August 2003

1023 Patrick Karl O'Brien, The Governance of Globalization: The Political Economy of Anglo-American Hegemony, 1793-2003, September 2003 
1024 Antonio Ciccone and Giovanni Peri, Skills' Substitutability and Technological Progress: U.S. States 1950-1990, September 2003

1025 Bjørn Sandvik, Optimal Taxation and Normalisations, September 2003

1026 Massimo Bordignon and Gilberto Turati, Bailing Out Expectations and Health Expenditure in Italy, September 2003

1027 José A. Herce, Namkee Ahn, Ricard Génova, and Joaquín Pereira, Bio-Demographic and Health Aspects of Ageing in the EU, September 2003

1028 John Komlos and Marieluise Baur, From the Tallest to (One of) the Fattest: The Enigmatic Fate of the American Population in the $20^{\text {th }}$ Century, September 2003

1029 Stefan Napel and Mika Widgrén, Bargaining and Distribution of Power in the EU's Conciliation Committee, September 2003

1030 Kai Li and Dale J. Poirier, Relationship Between Maternal Behavior During Pregnancy, Birth Outcome, and Early Childhood Development: An Exploratory Study, September 2003

1031 Ivar Ekeland, James J. Heckman, and Lars Nesheim, Identifcation and Estimation of Hedonic Models, September 2003

1032 Kjetil Bjorvatn and Alexander W. Cappelen, Decentralization and the Fate of Minorities, September 2003

1033 Lars-Erik Borge and Jørn Rattsø, The Relationships Between Costs and User Charges: The Case of a Norwegian Utility Service, September 2003

1034 Maureen Were and Nancy N. Nafula, An Assessment of the Impact of HIV/AIDS on Economic Growth: The Case of Kenya, September 2003

1035 A. Lans Bovenberg, Tax Policy and Labor Market Performance, September 2003

1036 Peter Birch Sørensen, Neutral Taxation of Shareholder Income: A Norwegian Tax Reform Proposal, September 2003

1037 Roberta Dessi and Sheilagh Ogilvie, Social Capital and Collusion: The Case of Merchant Guilds, September 2003

1038 Alessandra Casarico and Carlo Devillanova, Capital-skill Complementarity and the Redistributive Effects of Social Security Reform, September 2003

1039 Assaf Razin and Efraim Sadka, Privatizing Social Security Under Balanced-Budget Constraints: A Political-Economy Approach, September 2003

1040 Michele Moretto, Paolo M. Panteghini, and Carlo Scarpa, Investment Size and Firm's Value under Profit Sharing Regulation, September 2003 
1041 A. Lans Bovenberg and Peter Birch Sørensen, Improving the Equity-Efficiency Tradeoff: Mandatory Savings Accounts for Social Insurance, September 2003

1042 Bas van Aarle, Harry Garretsen, and Florence Huart, Transatlantic Monetary and Fiscal Policy Interaction, September 2003

1043 Jerome L. Stein, Stochastic Optimal Control Modeling of Debt Crises, September 2003

1044 Thomas Stratmann, Tainted Money? Contribution Limits and the Effectiveness of Campaign Spending, September 2003

1045 Marianna Grimaldi and Paul De Grauwe, Bubbling and Crashing Exchange Rates, September 2003

1046 Assar Lindbeck and Dennis J. Snower, The Firm as a Pool of Factor Complementarities, September 2003

1047 Volker Grossmann, Firm Size and Diversification: Asymmetric Multiproduct Firms under Cournot Competition, September 2003

1048 Dan Anderberg, Insiders, Outsiders, and the Underground Economy, October 2003

1049 Jose Apesteguia, Steffen Huck and Jörg Oechssler, Imitation - Theory and Experimental Evidence, October 2003

1050 G. Abío, G. Mahieu and C. Patxot, On the Optimality of PAYG Pension Systems in an Endogenous Fertility Setting, October 2003

1051 Carlos Fonseca Marinheiro, Output Smoothing in EMU and OECD: Can We Forego Government Contribution? A Risk Sharing Approach, October 2003

1052 Olivier Bargain and Nicolas Moreau, Is the Collective Model of Labor Supply Useful for Tax Policy Analysis? A Simulation Exercise, October 2003

1053 Michael Artis, Is there a European Business Cycle?, October 2003

1054 Martin R. West and Ludger Wößmann, Which School Systems Sort Weaker Students into Smaller Classes? International Evidence, October 2003

1055 Annette Alstadsaeter, Income Tax, Consumption Value of Education, and the Choice of Educational Type, October 2003

1056 Ansgar Belke and Ralph Setzer, Exchange Rate Volatility and Employment Growth: Empirical Evidence from the CEE Economies, October 2003

1057 Carsten Hefeker, Structural Reforms and the Enlargement of Monetary Union, October 2003

1058 Henning Bohn and Charles Stuart, Voting and Nonlinear Taxes in a Stylized Representative Democracy, October 2003 
1059 Philippe Choné, David le Blanc and Isabelle Robert-Bobée, Female Labor Supply and Child Care in France, October 2003

1060 V. Anton Muscatelli, Patrizio Tirelli and Carmine Trecroci, Fiscal and Monetary Policy Interactions: Empirical Evidence and Optimal Policy Using a Structural New Keynesian Model, October 2003

1061 Helmuth Cremer and Pierre Pestieau, Wealth Transfer Taxation: A Survey, October 2003

1062 Henning Bohn, Will Social Security and Medicare Remain Viable as the U.S. Population is Aging? An Update, October 2003

1063 James M. Malcomson, Health Service Gatekeepers, October 2003

1064 Jakob von Weizsäcker, The Hayek Pension: An efficient minimum pension to complement the welfare state, October 2003

1065 Joerg Baten, Creating Firms for a New Century: Determinants of Firm Creation around 1900, October 2003

1066 Christian Keuschnigg, Public Policy and Venture Capital Backed Innovation, October 2003

1067 Thomas von Ungern-Sternberg, State Intervention on the Market for Natural Damage Insurance in Europe, October 2003

1068 Mark V. Pauly, Time, Risk, Precommitment, and Adverse Selection in Competitive Insurance Markets, October 2003

1069 Wolfgang Ochel, Decentralising Wage Bargaining in Germany - A Way to Increase Employment?, November 2003

1070 Jay Pil Choi, Patent Pools and Cross-Licensing in the Shadow of Patent Litigation, November 2003

1071 Martin Peitz and Patrick Waelbroeck, Piracy of Digital Products: A Critical Review of the Economics Literature, November 2003

1072 George Economides, Jim Malley, Apostolis Philippopoulos, and Ulrich Woitek, Electoral Uncertainty, Fiscal Policies \& Growth: Theory and Evidence from Germany, the UK and the US, November 2003

1073 Robert S. Chirinko and Julie Ann Elston, Finance, Control, and Profitability: The Influence of German Banks, November 2003

1074 Wolfgang Eggert and Martin Kolmar, The Taxation of Financial Capital under Asymmetric Information and the Tax-Competition Paradox, November 2003 